\title{
Impact of Foreign Direct Investment on Sectors of GDP Pakistan Perspective
}

\author{
Muhammad Ajmair ${ }^{1}$, Ashiq Hussain ${ }^{2}$ \\ 1, 2 Assistant Professor, Department of Economics, Mirpur University of science and Technology; ajmair@must.edu.pk
}

\begin{abstract}
The basic objective of this study was to check the impact of foreign direct investment on sectoral components of GDP (Agricultural Sector, Industrial Sector and Services Sector). Time series annual data from 1950 to 2010 was used and Engle Granger Cointegration(Two Step) Method was employed to get results. Augmented Dickey Fuller test was applied to check the stationarity of variable. All variable except foreign direct investment (FDI) were stationary at first difference and FDI was stationary at level. Regression analysis was consisted on two steps. In first step long run relationship was checked which was positive and significant. Residuals (ect) were generated and checked for unit root. Error correction term(ect) was stationary at level; it is the precondition of existence of long run relationship between dependent and independent variables. In second step, error correction model was estimated to check the short run relationship. Significant relationship was found between dependent and independent variables as the coefficient of error correction term(ect) was negative. Negative coefficient is the precondition of existence of short run relationship.
\end{abstract}

Keywords: FDI, GDP, Agricultural Sector, Industrial Sector, Services Sector, Cointegration.

JEL Classification: C22, C82, F21, O11

\section{Introduction}

(Borensztein et al.,1997), (Demurger,2002), (Hamdani et al., 2003), (Abbas et al., 2011), (Riza ,2012), (Gudaro,2012), (Moolio et al.,2013) and (Wahiba,2014) concluded that Foreign Direct Investment(FDI) affects Gross Domestic Product positively with certain conditions in different countries.

Foreign Direct Investment affects positively the small farmers' productivity (Msuya, 2007). Foreign Direct Investment is necessary not only for food security but also for agricultural sector to ensure food security (Na'iya et al., 2009).According to (Kavita, 2014) it has been observed globally that FDI has negative impact on agricultural sector as well as on economy if retailer corporations act as monopolists. FDI affects the productivity of agricultural sector negatively in long run and in short run its effect is positive (Iddrisu et al., 2015). FDI has positive impact on food and agriculture (Gopinath,--).

FDI affects the services sector positively and growing services sector has positive and significant impact on GDP (Sen, 2011). FDI is a major source of employment generation in economy (Bohra et.al, 2011). FDI affects the GDP positively and significantly (Badge et al., 2013). FDI in services sector also affects the performance of manufacturing sector (Duggan et al., 2013).

1.1 Objectives of the study are

To check the impact of Foreign Direct Investment on sectoral components of GDP (Agricultural Sector, Industrial Sector and Services Sector)

\subsection{Justification of Study}

Foreign Direct Investment is a major factor to affect agricultural sector growth, industrial sector growth and services sector growth positively; so, to check the impact of growth of Foreign Direct Investment, we include it in regression.

\section{Literature Review}

\subsection{Foreign Direct Investment (FDI) and GDP.}

Borensztein et al.(1997) applied cross-country regression framework while using 69 developing countries' data over the last two decades and concluded that FDI affects economic growth positively only when an advanced technological structure is available in the host economy.

Hamdani (2003) using 1965 to 1992 period data for 32 developing countries suggested that Domestic private investment has positive effect on economic growth as compared to FDI as it has adverse balance of payment consequences in Pakistan.

Weinberger et al. (2009) used aggregate data and concluded that there is the relationship between foreign direct investment, productivity, and economics growth.

Abbas et al.(2011), used the data for period 2001 to 2010 applying multiple regression models and concluded that there is positive and significant relationship between FDI and GDP in SAARC countries.

Gudaro(2012) used the data for period 1981 to 2010 applying multiple regression models and suggested positive and significant relationship between FDI and GDP of Pakistan

Riza (2012) used data of 1995-2011 period. Granger Causality Test based on error correction model and HoltzEakin, Newey and Rosen Panel Causality Test were applied. The conclusion was that the strong positive effect of FDI on GDP in ten E.C.O. member countries. 


\section{International Journal of Science and Research (IJSR) \\ ISSN (Online): 2319-7064 \\ Index Copernicus Value (2013): 6.14 | Impact Factor (2014): 5.611}

Moolio et al.(2013), used data for period of 1993-2011 by using simple regression analysis, Augmented Dickey-Fuller test, Durbin-Watson test, Breusch-Godfrey Serial Correlation LM test, Breusch-Pagan-Godfrey test, and Jarque-Bera test to find that FDI has positive effect on GDP in Cambodia.

Wahiba (2014) suggested the positive impact of FDI on Economic growth in Tunisia.

\subsection{Foreign Direct Investment (FDI) and Industrial Sector}

Demurger (2002) calculated total factor productivity of 23 manufacturing sectors in 29 provinces of China during period 1988-1994 and concluded that FDI has positive impact on economic growth but on the other hand FDI induced regional disparities.

\subsection{Foreign Direct Investment(FDI) and Agricultural Sector}

Msuya (2007) observed that FDI affects positively the small farmers who are major source of productivity in Tanzania. So inflow of FDI should be made possible in agricultural sector.

Na'iya et al.(2009) concluded that FDI is necessary not only for food security but also for agricultural sector to ensure food security in OIC.

According to Kavita, (2014) it has been observed globally that FDI has negative impact on agricultural sector as well as on economy if retailer corporations act as monopolists.

Iddrisu et al.(2015) used Johansen cointegration test for period 1980-2013 in Ghana and concluded that FDI affects the productivity of agricultural sector negatively in long run and in short run its effect is positive. Trade liberalization has positive and significant impact of FDI on agricultural sector in long run.

Gopinath concluded that FDI has positive impact on food and agriculture if trade liberalization are allowed as in the presence of trade liberalizations transfer of technology is possible in host countries.

\subsection{Foreign Direct Investment and Services Sector}

Sen (2011) used data for period 1970-2007, applied simple OLS estimation technique taking log of data series and suggested that FDI affects the services sector positively and growing services sector has positive and significant impact on GDP in India.

Bohra et.al(2011) using data for period 1991-2010 concluded that technology and managerial skills can be improved through FDI. FDI is a major source of employment generation in economy of India.

Badge et al.(2013) checked the impact of FDI inflows on economic development of India for the period of 2000 to 2010 using correlation technique. Results witnessed that FDI affects positively and significantly the GDP of India.
Duggan et al.(2013) used data for period 1997-2009 and concluded that FDI in services sector affects the performance of manufacturing sector in Indonesia.

\subsection{Research Gap}

In above mentioned literature review there are many studies which show the relationship of GDP with Foreign Direct Investment, Agricultural Sector with Foreign Direct Investment, Industrial Sector with Foreign Direct Investment and Services Sector with Foreign Direct Investment

But no single study was found that showed the impact of Foreign Direct Investment, on sectoral components of GDP (Agricultural Sector, Industrial Sector and Services Sector).

\section{Methodology and Data}

This section discusses the methodologies that are employed to meet the objectives of the study. The variables used in this study include lfdi stands for log of foreign direct investment, lgdp stands for log of gross domestic product, lagr stands for $\log$ of agricultural sector, lind stands for log of industrial sector and lser stands for log of services sector. The secondary annual data (1950-2010) is taken from the website of State Bank of Pakistan.

\subsection{Unit Root Test}

The most rigorous way is to use the Augmented Dickey Fuller (ADF) to check the stationarity of data which is the wider version of the standard Dickey Fuller (DF). This test is employed to verify the presence of unit root in the data series. If at least two variables are stationary at first difference and no variable is stationary at second difference , Engle Granger co integration model can be used for data analysis. ADF test results are in table 4.1 in results section.

\subsection{Model Specification}

Linear regression is an approach to modeling the relationship between a dependent variable and one or more explanatory variables denoted $X$. The case of one explanatory variable is called simple linear regression. The model stipulates the impact of foreign direct investment on sectoral components of GDP. The sequence is as follows: I used Engle Granger Co integration method that has two steps.

\subsubsection{Step: 1:-Testing for Cointegration}

In first step long run relationship is checked when at least two variables are stationary at first difference, remaining variables should be stationary at level and no one should be stationary at second difference. Model equation is as under. $\operatorname{lgdp}{ }_{\mathrm{t}}^{\mathrm{i}}=\mathrm{C}+\beta_{1}$ lfdi $_{\mathrm{t}}+\varepsilon_{\mathrm{t}}-----1$

$\mathrm{l}=\log$ of data series

${ }^{\mathrm{i}}=$ various components of gross domestic product (Agricultural(lagr), Industrial(lind) and Services(lser) Sectors) $\mathrm{t}=1950-2010$

$\beta_{\mathrm{s}}=$ coefficients of independent variables to show the relationship whether it is positive or negative. $\varepsilon^{\mathrm{i}}=\mathrm{N}\left(0, \sigma^{2}\right)$ 


\section{International Journal of Science and Research (IJSR) \\ ISSN (Online): 2319-7064 \\ Index Copernicus Value (2013): 6.14 | Impact Factor (2014): 5.611}

where : lgdp is log of gross domestic product, lser log of services sector, lind is log of industrial sector, lagr is log of agricultural sector and lfdi stands for log of foreign direct investment.

\subsubsection{Step: 2:- Estimating Error Correction Model}

Second step deals with the short run relationship between dependent and independent variables. Following shape of model is used to find short run relationship.

$\operatorname{dlgdp}{ }_{t}{ }_{t}=c+\beta_{1} \operatorname{dlfdi}_{\mathrm{t}}+\beta_{2}$ ect $(-1)+\varepsilon_{\mathrm{t}}$

dlfdi: difference of current and previous value of log of foreign direct investment data series

dlgdp ${ }^{\mathrm{i}}$ : difference of current and previous value of log of gdp, agricultural sector, industrial sector and services sector. ect(-1): first lag of residuals.

$\beta_{1 \text { and }} \beta_{2}$ are coefficients which show trend of independent variables.
$\varepsilon$ : Error term
c: constant or intercept

\section{Results}

\subsection{ADF Test Results}

In table 4.1 the ADF test results of unit root test of all the variables are presented that were calculated while using E.Views 8 . At $1^{\text {st }}$ difference all variables are stationary except lfdi .

\begin{tabular}{|c|c|c|c|c|}
\hline \multicolumn{5}{|c|}{ Table: 4.1} \\
\hline \multirow[t]{3}{*}{ Variables } & \multicolumn{4}{|c|}{ ADF test } \\
\hline & \multicolumn{2}{|c|}{ Level } & \multicolumn{2}{|c|}{ 1st Difference } \\
\hline & intercept & $\begin{array}{c}\text { Intercept \& } \\
\text { Trend }\end{array}$ & intercept & $\begin{array}{c}\text { Intercept \& } \\
\text { Trend }\end{array}$ \\
\hline Ifdi & \begin{tabular}{|c|}
$-1.98 * * * *$ \\
$(-2.59)$ \\
\end{tabular} & $\begin{array}{c}-3.54 * * \\
(-3.48) \\
\end{array}$ & $\begin{array}{l}-5.60 * \\
(-3.55)\end{array}$ & $\begin{array}{l}-5.61 * \\
(-4.13) \\
\end{array}$ \\
\hline lgdp & \begin{tabular}{|c|}
$0.28 * * *$ \\
$(-2.59)$
\end{tabular} & $\begin{array}{c}-2.50 * * * \\
(-3.17)\end{array}$ & $\begin{array}{l}-7.81 * \\
(-3.55)\end{array}$ & $\begin{array}{l}-7.86^{*} \\
(-4.12)\end{array}$ \\
\hline lagr & $\begin{array}{c}0.17 * * * \\
(-2.59)\end{array}$ & $\begin{array}{c}-2.50 * * * \\
(-3.17)\end{array}$ & $\begin{array}{l}-7.91 * \\
(-3.55)\end{array}$ & $\begin{array}{l}-7.97 * \\
(-4.92)\end{array}$ \\
\hline lind & $\begin{array}{c}0.06 \\
(-2.59)\end{array}$ & $\begin{array}{c}-2.63 * * * \\
(-3.17)\end{array}$ & $\begin{array}{l}-7.77^{*} \\
(-3.55)\end{array}$ & $\begin{array}{l}-7.74^{*} \\
(-4.12)\end{array}$ \\
\hline Iser & $\begin{array}{c}0.23 * * * \\
(-2.59)\end{array}$ & $\begin{array}{c}-2.51 * * * \\
(-3.17)\end{array}$ & $\begin{array}{l}-7.81 * \\
(-3.55)\end{array}$ & $\begin{array}{l}-7.84^{*} \\
(-4.12)\end{array}$ \\
\hline
\end{tabular}

Note: * denotes the rejection of the null hypothesis at $1 \%$ level of significance, **denotes the rejection of the null hypothesis at 5 percent level of significance and *** denotes the rejection of the null hypothesis at $10 \%$ level of significance and Values in the parenthesis are MacKinnon critical values for rejection of hypothesis of a unit root. Legend:-lfdi stands for log of foreign direct investment, lgdp stands for log of gross domestic product, lagr stands for log of agricultural sector, lind stands for log of industrial sector, and lser stands for log of services sector.

\subsection{Regression Results}

\subsubsection{Step: 1:-Testing for Long Run Relationship}

Regression results of four different linear relationships are as under in table 4.2 which show that foreign direct investment affects the growth of GDP, growth of Agricultural Sectoral, growth of Industrial Sector and growth of Services Sector positively and significantly. It is shown by positive values of coefficients and T.values in bracket. P.values $(0.0000)$ are less than 0.05 that means there is significant relationship. Average value of $\mathbf{R}^{\mathbf{2}}$ is 0.53 that shows $53 \%$ variation in sectoral components of GDP(Agricultural(lagr), Industrial(lind) and Services(lser) Sectors) is due to foreign direct investment.

\begin{tabular}{|c|c|c|}
\hline \multicolumn{3}{|c|}{ Table: 4.2} \\
\hline Variables & Constant & lfdi \\
\hline lgdp & $\begin{array}{c}4.67 \\
(46.37)\end{array}$ & $\begin{array}{c}0.83 \\
(8.23)\end{array}$ \\
\hline P. Values & 0.0000 & 0.0000 \\
\hline $\mathbf{R}^{2}$ & \multicolumn{2}{|c|}{0.53} \\
\hline Variables & Constant & Ifdi \\
\hline lagr & $\begin{array}{c}4.23 \\
(48.34)\end{array}$ & $\begin{array}{c}0.73 \\
(8.34)\end{array}$ \\
\hline P. Values & 0.0000 & 0.0000 \\
\hline $\mathbf{R}^{2}$ & \multicolumn{2}{|c|}{0.54} \\
\hline Variables & Constant & Ifdi \\
\hline Lind & $\begin{array}{c}3.96 \\
(35.57) \\
\end{array}$ & $\begin{array}{c}0.90 \\
(8.05) \\
\end{array}$ \\
\hline P. Values & 0.0000 & 0.0000 \\
\hline $\mathbf{R}^{2}$ & \multicolumn{2}{|c|}{0.52} \\
\hline Variables & Constant & Ifdi \\
\hline Iser & $\begin{array}{c}4.29 \\
(40.98) \\
\end{array}$ & $\begin{array}{c}0.87 \\
(8.11) \\
\end{array}$ \\
\hline P. Values & 0.0000 & 0.0000 \\
\hline $\mathbf{R}^{2}$ & \multicolumn{2}{|c|}{0.53} \\
\hline
\end{tabular}

The residuals from eq. 1 were tested for stationarity and the results are as follows in table 4.3. The residual series is stationary at level or series is $\mathrm{I}(0)$ that means series is stationary at level. Condition of stationarity is that ADF tstatistic value (3.78) should be greater in absolute terms than critical value at $1 \%$ level of significance. It implies that there is long run relationship between foreign direct investment and sectoral components of GDP. As it is the precondition of long run relationship that residual series should be stationary at level.

\begin{tabular}{|c|c|c|}
\hline \multirow{3}{|c|}{ Table: 4.3} \\
\hline \multirow{2}{*}{ Variables } & \multicolumn{2}{|c|}{ ADF test } \\
\cline { 2 - 3 } & Level & P-value \\
\hline \multirow{2}{*}{ ect } & $-3.78^{*}$ & 0.0051 \\
& $(-3.55)$ & \\
\hline
\end{tabular}

\subsection{2- Step: 2:- Estimating Error Correction Model for} Short Run Relationship

Results of second step of Engle Granger Cointegration method to check the short run relationship are as under in the table 4.4. Precondition of second step is that the coefficient of residuals should be negative which is fulfilling in each equation results. It means there is short run relationship between foreign direct investment and sectoral components of GDP. Overall we can say that cointegration exists between dependent and independent variables. 


\section{International Journal of Science and Research (IJSR) \\ ISSN (Online): 2319-7064}

Index Copernicus Value (2013): 6.14 | Impact Factor (2014): 5.611

\begin{tabular}{|c|c|c|}
\hline \multicolumn{3}{|c|}{ Table: 4.4} \\
\hline Variables & Dlfdi & Ect(-1) \\
\hline dlgdp & -0.012 & -0.02 \\
& $(-0.23)$ & $(-0.55)$ \\
\hline P. Values & 0.8193 & 0.5818 \\
\hline Variables & Dlfdi & Ect(-1) \\
\hline dlagr & -0.01 & -0.02 \\
& $(-0.23)$ & $(-0.53)$ \\
\hline P. Values & 0.8156 & 0.5961 \\
\hline Variables & Dlfdi & Ect(-1) \\
\hline dlind & -0.00 & -0.02 \\
& $(-0.05)$ & $(-0.53)$ \\
\hline P. Values & 0.9589 & 0.5961 \\
\hline Variables & Dlfdi & Ect(-1) \\
\hline dlagr & -0.01 & -0.02 \\
& $(-0.22)$ & $(-0.63)$ \\
\hline P. Values & 0.8271 & 0.5298 \\
\hline \multicolumn{2}{|c|}{}
\end{tabular}

\section{Conclusion and Recommendations}

The basic objective of this study was to check the impact of foreign direct investment on sectoral components of GDP(Agricultural Sector, Industrial Sector and Services Sector). Time series annual data from 1950 to 2010 was used and Engle Granger Cointegration (Two Step) Method was employed to get results. Augmented Dickey Fuller test was applied to check the stationarity of variable. E. Views version 8 was used to analyze the data.

All variable except foreign direct investment (FDI) were stationary at first difference and FDI was stationary at level. Regression analysis was consisted on two steps. In first step long run relationship was checked which was positive and significant. Residuals (ect) were generated and checked for unit root. Error correction term(ect) was stationary at level; it is the precondition of existence of long run relationship between dependent and independent variables. In second step, error correction model was estimated to check the short run relationship. Significant relationship was found between dependent and independent variables as the coefficient of error correction term(ect) was negative. Negative coefficient is the precondition of existence of short run relationship.

Government should focus on attracting foreign direct investment in three sectoral components (Agricultural Sector, Industrial Sector and Services Sector) equally to have consistent long run growth in GDP of Pakistan.

\section{References}

[1] Abbas Q. et al(2011), "Impact of Foreign Direct Investment on Gross Domestic Product”, Global Journal of Management and Business Research Volume 11 Issue 8 Version 1.

[2] Borensztein et al.(1997), "How does foreign direct investment affect economic growth?'International Monetary Fund, Research Department, Washington DC 20431 USA.

[3] Bohra N.S.et.al.(2011), "Foreign Direct Investment (FDI) IN India Services Sector (A Study of Post Liberalization)", Int. J. Eco. Res., 2(2), 10-18, ISSN: 2229-6158.
[4] Chen Y. \& Demurger S. (2002) "Foreign Direct Investment and Manufacturing Productivity in China".

[5] Contessi S. \& Weinberger A.(2009) "Foreign Direct Investment, Productivity and Country Growth: An Overview", Federal Reserve Bank of St. Louis Review, March/April 2009, 91(2), pp. 61-78.

[6] Dwivedi P. \& Badge J.(2013), "Impact of FDI Inflow on Service Sector in India: An Empirical Analysis" International Journal of Management Research and Business Strategy, Vol. 2, No. 3.

[7] Duggan V.et al. (2013), "Can Open Services Sector FDI Policy Enhance Manufacturing Productivity? Evidence from Indonesia" Poverty Reduction and Economic Management (PREM) Network, number106.

[8] Eatzaz A.\& Hamdani A. (2003), "The Role of Foreign Direct Investment in Economic Growth" Pakistan Economic and Social Review, Volume XLI, No. 1\&2, pp. 29-43.

[9] Faiza Umer F.\& Alam S.(2013) "Effect of Openness to Trade and FDI on Industrial Sector Growth: A Case Study for Pakistan", The Romanian Economic Journal XVI no. 48.

[10]Gudaro A.M.(2012), "Impact of Foreign Direct Investment on Economic Growth: A Case Study of Pakistan", Journal of Management and Social Sciences Vol. 8, No. 2, pp.22-30.

[11]Heang L.G.\& Moolio P.(2013), “The Relationship between Gross Domestic Product and Foreign Direct Investment: The Case of Cambodia", KASBIT Business Journal, 6:87-99.

[12] Riza D.A. (2012), "Foreign Direct Investment and Gross Domestic Product: An Application on ECO Region (1995-2011)”, International Journal of Business and Social Science Vol. 3 No. 22.

[13] Gopinath M.(--), "Foreign Direct Investment in Food and Agricultural Sectors".

[14] Iddrisu A.A. et al.(2015), "The Impact of Foreign Direct Investment (FDI) on the performance of the Agricultural Sector in Ghana", International Journal of Academic Research in Business and Social Sciences, Vol. 5, No. 7, ISSN: 2222-6990

[15] Kavita S.K.(2014), "Foreign Direct Investment in Indian Agricultural Sector: Opportunities and Challenges States", report/article, socio - economic voices, www.indiastat.com .

[16] Msuya E. (2007), "The Impact of Foreign Direct Investment on Agricultural Productivity and Poverty Reduction in Tanzania", online at http://mpra.ub.unimuenchen.de/3671/MPRA Paper No. 3671.

[17] Suleman A. \& Na'iya I.I.(2009), “Fostering Intra-Oic. FDI in The Agriculture Sector", Occasional Paper No. 14, Economic Policy and Statistics Department.

[18] Wahiba N.F. (2014), "Impact of Foreign Direct Investment on Economic Growth in Tunisia", Academic Research International Vol. 5(2). 